\title{
Robert W. Woodruff Library of the Atlanta University Center, Custodian of the Morehouse College Martin Luther King, Jr. Collection: "Until Further Notice"
}

On June 23, 2006, the American Library Association was holding its Annual Conference in New Orleans, Louisiana, the first major conference to return to the city post Hurricane Katrina. My scheduled visit of four days was abruptly cut short as a result of two communications: a call from Walter Massey, President of Morehouse College in Atlanta, Georgia, and an e-mail from William Potter, Dean of the University of Georgia Libraries. By the time the day was over, I learned that a collection of manuscripts and books documenting many of the writings, speeches, and notes of Dr. Martin Luther King, Jr. that was originally slated for auction had instead been purchased by a group of Atlantans for an astounding price of $\$ 32$ million. The Robert W. Woodruff Library of the Atlanta University Center had been selected to receive and house this extraordinary collection.

This article will describe some of the events that transpired relative to that collection, from the point of its purchase to the moment of its receipt at the library. It will also discuss, from the administrator's point of view, opportunities and challenges associated with assuming the role of custodian for the Morehouse College Martin Luther King, Jr. Collection.

The Robert W. Woodruff Library of the Atlanta University Center (AUC) is an independent 501(c) 3 organization operating to provide academic library services and resources for the exclusive benefit of its member institutions-Clark Atlanta University, the Interdenominational Theological Center, Morehouse College, and Spelman College. The library is governed by a nine-member Board of Trustees that includes the four AUC presidents, three members-at-large not affiliated with the AUC (selected for their particular expertise), an academic officer, a faculty member, and the Chief Executive Officer/Library Director. The CEO/Library Director provides leadership for the library and is responsible for transforming the library in accordance with its vision "to reflect the excellence of our member institutions by being the first and best choice" for its community of users. 
The library was established in 1982 with a unique mission - to provide cooperative library services to a consortium of Historically Black Colleges and Universities. Twenty-five years later, the Woodruff Library remains the country's only academic library to do so and is one of only two or three academic libraries serving a consortium of private colleges. The library operates without an infrastructure dependence on any one of its member institutions. It is a library in transformation: fiscally, physically, and programmatically, as well as in its reputation. Covering more than 220,000 square feet, with seating for more than 1,200, the library features a learning environment that caters to the research and study needs of an academically diverse population of just over 10,000 enrolled students and several hundred faculty. All users have access to staff expertise, group study and meeting spaces, and the library holdings of over 1.6 million print and electronic resources.

Complementing the library's resources is an extensive Archives and Special Collections department that houses over 7,000 linear feet of manuscript collections and organizational records, and over 35,000 books, pamphlets, and other printed materials. The core of the collection is built from the Atlanta University Trevor Arnett Library Negro Collection that was established in 1925, a collection that is well known and extensively used and cited by scholars. The Negro Collection, along with special collections materials from the other AUC schools, was transferred to the Woodruff Library when the schools combined their libraries in 1982. Now in its 81 st year, the archival holdings and special collections continue to evolve and develop under the auspices of the Woodruff Library. They document the life and culture of African Americans, particularly in the southeastern United States, with an emphasis in the areas of education, literature, politics, government, social work, civil rights, and race relations. Among the holdings are the papers of abolitionists Thomas Clarkson and John Brown; the Countee Cullen/Harold Jackman Memorial Collection and Hoyt Fuller Papers that focus on black contributions to literature and the arts; and records of educational organizations such as the Freedmen's Aid Society, the Southern Education Foundation, the College Language Association, and the United Negro College Fund. Recent acquisitions include the papers of former Atlanta Mayor Maynard Jackson; educators and scholars C. Eric Lincoln and Walter Rodney; jazz flutist Wayman Carver; and the personal library of Africanist, educator and author, John Henrik Clarke. ${ }^{1}$

On June 11, 2006, the Atlanta Journal-Constitution published a story about the pending auction of a collection of Martin Luther King, Jr.'s papers and books that were owned by the King Family Estate. Coretta Scott King had turned over the items in this King Collection to Sotheby's nearly nine years ago. Seeking the counsel of a reputable auc-

1. Additional information about the library and archives can be found at the Woodruff Library's Web site at www.auctr.edu. 
tion house, Mrs. King provided access for their curators to the family home in Atlanta where materials were stored. During that time, manuscripts and books and a few artifacts were loosely inventoried, boxed, and shipped to Sotheby's in New York City, where they were held for eventual auction. By June 12, 2006, the first steps had been taken in securing the collection for Morehouse College. Former Atlanta Mayor Andrew Young, who had been one of King's closest aides, urged current Atlanta Mayor Shirley Franklin to initiate an effort to purchase the papers. In eleven days a strategy had been formed, a home for the collection identified, the $\$ 32$ million purchase price financed, and a vast network of cooperation among the city's leaders in business, education, government, foundation, and civic communities enjoined. ${ }^{2}$

The actual purchase of the collection was made by a loan through Sun Trust Bank to the "ATLCF Collections LLC," a company owned and operated by the Community Foundation for Greater Atlanta. It is a two-year loan where, upon payment, the title for the King Collection will be transferred to Morehouse College. The King Family Estate retains intellectual property rights, something not uncommon with literary papers: the Boston University King Collection has functioned easily with such a copyright arrangement for over 43 years.

On June 29, 2006, by which time the sale of the King Collection had been secured, the Head of Archives and Special Collections at Woodruff and I (as CEO/Library Director) went to New York City to see the collection as it was displayed in the Sotheby's galleries. There we met with Sotheby's officials, toured the vault and storage areas, and viewed other items from the collection that had never been put on display but were still in the original cartons as they were shipped from Atlanta to New York. The following evening, the Atlanta stakeholders were flown in for dinner and a viewing of the displayed collection. Included among the guests were Mayor Shirley Franklin, Congressman John Lewis, former Mayor Andrew Young, members of the King family, the Atlanta History Center administration staff, and a majority of the partners who had acted in support of Mayor Franklin's bid to bring the King papers back to Atlanta.

Once they returned to Atlanta, the Archives and Special Collections staff confirmed receipt of 71 cartons from Sotheby's auction house and began the work of rehousing the collection in archival containers and placing them on archival shelving in a secure, environmentally monitored vault. The collection totals 32 linear feet, and 1,000 books, periodicals, and pamphlets. Included are sermons, speeches, notes, note cards, drafts of writings, galley proofs, student papers, correspondence, financial papers, greeting cards, travel itineraries, a few photographs, news clippings, flyers,

2. For further information, see "Case Study: Securing the King Papers" at www.ahmann.com/index. php?page=aboutking (accessed April 27, 2007). 
brochures, invitations, programs, press releases, reports, writings of others, meeting agendas, and lists. Although relatively small in size, the collection contains some of the most historically valuable documents of the civil rights movement, with writings authored by Dr. King, including the Letter from Birmingham Jail, his Nobel Peace Prize speech and lecture, and pages from the March on Washington speech ("I have a dream"), many with handwritten notations and/or edits. The books are filled with King's handwritten marginalia. There are numerous autographed titles, as well as translations into foreign languages of books King authored.

The collection has no consistent order, and it appears that the files have been searched through and materials pulled and rearranged repeatedly over many years. Thus, processing activities will require significant planning, decision making, and effort to bring about the best arrangement protocol. It is probable that much of the collection will be processed to the item level, given its significance and expected use. The primary goal is to gain control over the Morehouse College Martin Luther King, Jr. Collection and to prepare it for research access by arranging and describing the collection, preparing an EAD finding aid, creating bibliographic records for books and manuscripts, and addressing conservation needs. Consideration will also be given to microfilm and digital reformatting for security, preservation, and access.

The number of stakeholders involved in the purchase included more than fifty different corporate entities and individuals - each with his or her own expectation of what should happen to the collection when it was returned to Atlanta and where it should be housed. Many qualified institutions in and around greater Atlanta were prepared to offer their resources and expertise for the King papers and books, including Emory University, the University of Georgia, the Atlanta History Center, the Auburn Avenue Research Center, and others. However, upon learning that Morehouse College's library, the Robert W. Woodruff Library, had a strong and reputable archival program that could properly house and secure the collection, it was decided to transfer the collection to the care of the Woodruff Library. This is an especially appropriate designation, since Dr. King was one of many members of the King family to attend Morehouse College: others included his grandfather, his father, his brother, and both of his sons. ${ }^{3}$ This educational and historical relationship, along with the endorsement of the King Family Estate, and the capacity of the Woodruff Library facility and its archives, reinforces the decision made to transfer the collection to Morehouse College.

But when news of the acquisition initially made its way to the local and national press, the first thirty days were filled with fact, fiction, editorializing, and questions concerning the capacity of Morehouse College to handle such an important and valuable collection. A vigorous public discussion took place in various newspapers

3. See www.morehouse.edu/kingcollection/pdf/King\%20Fact\%20Sheet.pdf (accessed May 8, 2007). 
across the country. The editorials and feature articles in the Atlanta Journal-Constitution became a daily read. Various historians, King scholars, and opinion makers celebrated the rescue of the collection from auction, while simultaneously debating as to the best place to house this national treasure. There were numerous erroneous comments, describing the Morehouse library and archives as "small," or "being located in a damp and dark basement of an older campus building," or even some reports that the college had no library at all. But such statements presented an opportunity for the Woodruff Library to improve its visibility and to provide for the community a clear picture of the history and capacity of the library and its archives.

On July 11, 2006, the Atlanta Journal-Constitution published a front page feature article, along with a color photograph, promoting the Woodruff Library, the archives, and its collections and staff expertise under the direction of Karen Jefferson, Head of the Archives and Special Collections. The Woodruff Library was described as an institution undergoing change, and one that had a strategic plan outlining the necessary actions for transformation of the library and a vision of anticipated improvement of its reputation as a service provider. The positive media attention was an administrator's dream and provided the perfect kind of promotion and recognition for the library. Clearly, the King Collection was about more than the receipt of a prestigious acquisition for the library and archives: the collection immediately became the impetus for initiating a campaign to restore awareness of the 81-year-old Archives and Special Collections department and to highlight the dramatic changes the library was making in its strategic plan to address the needs of the 21st-century learner.

With public recognition came more inquiries from the media and the stakeholder community, along with an even greater need for the library to demonstrate its legitimacy. It was important that the library show that it had the resources to receive and house the King Collection, and that it had in the past, and would continue in the future, to perform in accordance with accepted archival standards (although the meaning and usefulness of such standards are little known and often misunderstood to most outside the archival profession). The legacy of Martin Luther King, Jr. is important to people around the world. To assure them that the King Collection will be properly cared for, it is essential that an awareness of professional archival values and practices be shared with as many people outside the profession as possible. Educating the public_including campus faculties and administrations, City of Atlanta leadership, and the Board of the Robert W. Woodruff Library-became, and continues to be, a priority in all library communications. The meaning of scholarly access to a collection, as contrasted to an exhibition of a collection, and the distinction among the mis- 
sions of a library, an archive, or a museum, continue to be core lessons taught in the ongoing awareness campaign for key stakeholders, potential contributors, and the public.

The media's abiding interest in the Morehouse College King Collection provides an excellent vehicle to publicize our message. It has also been a learning experience for the library staff, involving a commitment of many hours of work in planning and production. Feature stories have been published in numerous local and national publications, including The New York Times. In addition, profiles on the King Collection and the Woodruff Library have been broadcast on National Public Radio and all local affiliates of the major networks. CNN produced a 5-part series and an hour-long documentary, "MLK: Words That Changed a Nation," chronicling major events within the Civil Rights Movement using excerpts from speeches and sermons found within the Morehouse King Collection and interviews with living civil rights figures. The Woodruff Library Head of Archives also appeared on CNN on the 2007 King Holiday, and I have been featured on local talk shows and special segments of programs that focus on the King Collection acquisition.

Morehouse College's commitment to the preservation and access of the King Collection is encapsulated in President Walter Massey's statements presented at the October 2006 press conference and in every subsequent media interview and speech he has given about the collection. He spoke of the college's responsibility for the collection as a three-pronged commitment: Stewardship, Partnership, and Scholarship. His careful assessment of and faith in the expertise and resources of Woodruff Library comes under the auspices of the stewardship role. The partnership role considers exhibitions and programming, and the scholarship commitment speaks to research access.

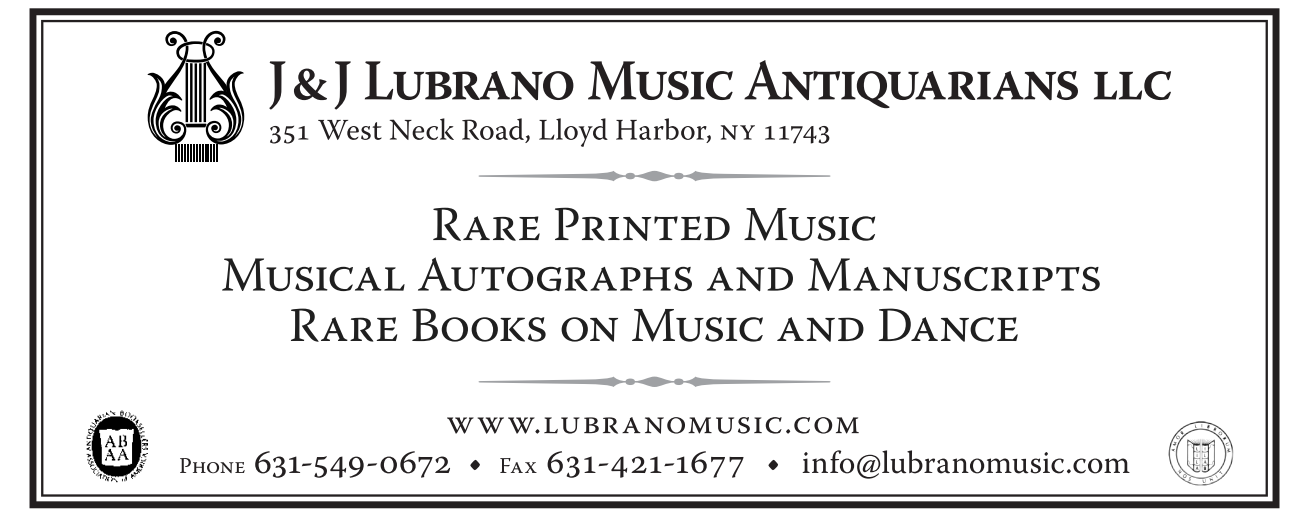


To administer a collection that has so many stakeholders, and to fulfill the responsibilities of the library's mission, a formal agreement was established between Morehouse College and the Woodruff Library. Charting new territory for such a unique collaboration required many hours of working through the details of a document that would clearly outline the areas of responsibilities and authority for each institution. The terms were carefully crafted to ensure that it did not compromise the formal agreements in place between Morehouse College and the other stakeholders, including the ATLCF Collections and the King Family Estate. The agreement identifies the library as the custodian and agent for the college, acting on its behalf to perform services for the custody, care, storage, inventory, maintenance, and research access of the collection. Other issues set forth are associated with risk, security, and intellectual property rights, and designates the official name of the collection as the "Morehouse College Martin Luther King, Jr. Collection." It is through this agreement and the expression of Mayor Shirley Franklin that the Robert W. Woodruff Library is affirmed as the custodian of the Martin Luther King, Jr. Collection "until further notice."

Throughout the days of preparing for receipt of the collection, the library received encouragement from our professional colleagues. Many individuals contacted us to express their support for the decision to place the collection at Morehouse College and in the custody of its library. It was the right decision. During the period of public debate about our ability to do the job, it was the endorsement of William Potter, Dean of Libraries at the University of Georgia, that served to quiet a sea of voices. In a June 28, 2006, letter to Morehouse College President Walter Massey, Potter stated that "the space is suitable to the housing of this collection. The staff $\ldots$ is highly professional and well regarded. The papers can be received and housed at the Woodruff Library immediately."

Perhaps one of the more challenging administrative tasks was arranging for transit of the collection from New York to Atlanta. Given its value and the intricacies of the purchase and custodial agreements, the requirements of underwriters for coverage of the collection, at all times and in all places, was daunting. There were many conversations and messages between the shipper and the library about insurance requirements, confidentiality, exchange of inventory data, signoffs authorizing the shipping company to participate in the packing process, driver credentialing, pricing, temperature and tracking en route, and overall communications. When the collection arrived on September 14, 2006, without ceremony (though recorded by Morehouse College videographers), the moment of turnover to Woodruff Library staff was one of sheer delight and emotional intensity that could be seen in the eyes and felt in the hearts of the library administration, archival staff, and security and communications personnel who were on hand. 
There is a very strong and collegial community of librarians and archivists in greater Atlanta that has worked collaboratively on numerous projects over the years. Some observers expressed surprise to find this cooperative climate in a profession where acquisitions of collections often forces institutions to be competitors. Collaboration has been the key to the success of many of the library and archival ventures involving the King Collection. Collaboration was crucial to the planning and the installation of the first public museum-quality exhibition, "I Have a Dream": The Morehouse College Martin Luther King, Jr. Collection, displayed from January 15 through May 13, 2007, at the Atlanta History Center (AHC). Because of a concerted collegial effort, the exhibit was mounted in four months - an effort that would normally require a two-year planning and preparation process. During the five-month run of the exhibit, more than 65,000 visitors viewed the installation, the largest visitorship for an AHC exhibition displayed over a comparable time period.

In its role as custodian, the library must maintain relationships and communicate and work with several entities. The Woodruff Library works closely with Morehouse College administrators, including the Office of the President, the chief academic officer, the director of institutional advancement, legal counsel, the chief financial officer, and communications and public relations directors. The college is establishing an Office of the Morehouse College Martin Luther King, Jr. Collection to manage issues that are beyond those associated with care, preservation, and research access and has hired, under recommendation of the library, a chief consulting archivist to work with the library in fulfilling the services outlined in the working agreement. Serving in this capacity is Brenda S. Banks, recently retired Deputy Director of the Georgia Department of Archives and History and former president of both the Society of American Archivists and the Society of Georgia Archivists. She is a strong advocate for adherence to standards, policies, and procedures who will serve to protect the collection and expedite access to it.

\section{RAY CHASTEEN RARE BOOKS}

ACTIVELY QUOTING NONFICTION

SEND TOPICS WANTED TO: RCHASTEEN@EARTHLINK.NET 
Another newly established group of stakeholders with whom the library collaborates is the Morehouse College King Collection National Advisory Board. The Board includes several noted historians, as well as King scholars, curators, and Morehouse College trustees. The chief consulting archivist and I (as Woodruff Library CEO/Library Director) serve in an ex-officio capacity. The Board exists to advise the college on policy, practice, and various matters associated with national exhibition, programming, and promotion of the collection. There is also a local advisory board appointed by the Mayor of Atlanta to provide a voice and input from the local community. The return to Atlanta of the King papers has served as a catalyst for the City of Atlanta to advance a much desired, yet long delayed, concept for a museum centered on civil and human rights. The archival, library, and museum communities have an important part to play in assisting the City with these plans. The King Collection has stimulated local and national interest in the role and contribution that libraries and archives make to the building of community, to preservation of the past, and to economic prosperity.

Prior to its designation as custodian of the King Collection, the Woodruff Library had developed a plan for improving aspects of its physical infrastructure that included environmental controls, as well as enhancements to its safety and security measures. In anticipation of the receipt of the King Collection, library administration made the decision to begin some of these capital improvements early and to expand the scope of selected projects to include the archives. Among the enhancements was a security upgrade for the library, a new HVAC system installed in the vault exclusively for preservation of the King Collection, and renovations to the offices and storage facilities in the Archives and Special Collections.

The opportunity to act as custodian of the King Collection aids the Woodruff Library in its efforts to advance our strategic goals. In addition to the physical improvements, the staff has been reorganized. Grant funding from the Andrew W. Mellon Foundation has made it possible to hire additional staff to process the collection and to support preservation needs. A financial investment has also been made in more technology and training to increase the effective management of the archives. The library has been able to embark on a plan to address the existing processing backlog in the archives, while simultaneously completing its obligation to prepare the Morehouse College King Collection for scholarly access.

To be involved in the care, preservation, and provision of access to the manuscripts, books, and other materials of the Morehouse College Martin Luther King, 
Jr. Collection is a rare opportunity and a privilege. Its importance extends beyond the students and faculty of Morehouse, for it is central to the story of the struggle for rights, recognition, and respect for African Americans, and it has wider national and global implications as a fundamental resource and guide for all people who in demand human rights. To this point, and in accordance with the library's mission, the Woodruff Library has established collaborative relationships with other institutions that hold significant King collections. The Howard Gotlieb Archival Research Center of Boston University and the Martin Luther King, Jr. Research and Education Institute at Stanford University are early collaborators, and there will no doubt be others involved in our collaborative strategy to streamline the research process and improve the scholar's search results.

The Robert W. Woodruff Library of the Atlanta University Center has been transformed by the excitement, opportunity, and challenge of housing this historical collection. Each box, each book in the King Collection provides a new and often unique view of the dream, the brilliance, and the passion of Martin Luther King, Jr. The administration of the library is cognizant of the tremendous responsibility to care for, preserve, and provide access to this collection and is appreciative of the challenges and the opportunity to provide custodial care "until further notice."

INDEX TO ADVERTISERS




\title{
Save the Date for 2008
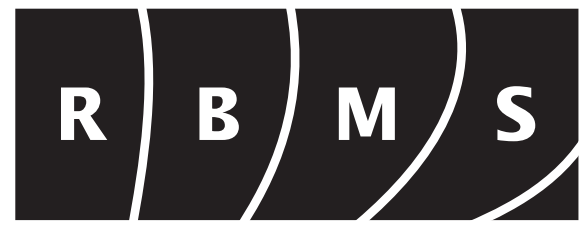

\author{
June $24-27,2008$ \\ Los Angeles, California
}

\section{Rare and Special Bytes: Special Collections in the Digital Era}

"Rare and Special Bytes: Special Collections in the Digital Era" will address many of the questions that both excite and vex special collections librarians and archivists. From intellectual property issues to selecting the materials researchers want to long-term accessibility of the files to the potential for mass digitization of rare materials, this preconference will explore the challenges and opportunities facing us in the 21 st century. Taking advantage of the proximity to The Getty Center and the generous support of the Research Library at the Getty Research Institute, the preconference will take place at The Getty on Thursday enabling attendees to discover the many delights it has to offer.

Registration will open in February. Please check the RBMS Website in the coming months for further details.

\section{http://www.rbms.info}

